\title{
COMPLEMENT RECEPTORS: SPECIFIC DETECTION BY MOLECULAR COMPLEXES
}

\author{
JEFFREY COSSMAN *, JOSEPH C. GLORIOSO and RICHARD ADLER \\ Department of Pathology, Unit for Laboratory Animal Medicine, and Department of \\ Human Genetics, University of Michigan Medical School, Ann Arbor, MI, U.S.A.
}

(Received 3 June 1977, accepted 29 July 1977)

Immune complexes of BSA-anti BSA ( $\operatorname{IgG~F}\left(\mathrm{ab}^{\prime}\right) 2$ ) will activate human complement by the alternate pathway. The $\mathrm{C} 3$ bound to these complexes binds to human peripheral blood mononuclear cells which bear complement receptors. This interaction is visualized by fluoresceinated antigen (BSA-FITC) or fluorescein conjugated antisera directed at the C3 component of complement. The assay appears to be more sensitive than the usual IgMEAC rosette technique and correlates well with the rosette method.

\section{INTRODUCTION}

Cell surface receptors for the third component of complement (C3) have been detected on B lymphocytes (Bianco, 1970), macrophages (Lay, 1968), polymorphonuclear neutrophils (Henson, 1968), eosinophils (Gupta, 1976) and renal glomeruli (Gelfand, 1975). Cells bearing C3 receptors are identified by their ability to form rosettes with sheep erythrocytes (E) sensitized with antibody (usually IgM) and complement (IgMEAC) (Lay, 1968). Complement receptors have also been identified by using bacterial organisms on which complement is fixed to the bacterial cell wall by the alternate complement pathway (Gelfand, 1976). Fc receptor binding does not appear to take place with either the bacterial (Gelfand, 1976) or IgMEAC assay (Shevach, 1973).

Alternatively, C3 receptors can be detected with soluble antigen-antibody complement complexes. These cell bound complexes may be identified

\footnotetext{
* Present address: Laboratory of Pathology, National Cancer Institute, National Institutes of Health, Bethesda, MD, U.S.A.
}

\begin{abstract}
Abbreviations used in this paper: BSA, bovine serum albumin; C, complement; C-Mo, mouse complement; $\mathrm{C}-\mathrm{Hu}$, human complement; NHS, normal human serum; $\mathrm{C} 3$, third component of complement; $\mathrm{C} 4$, fourth component of complement; $\mathrm{BSA}-\mathrm{F}(\mathrm{ab}) 2-\mathrm{C}$, antigen-antibody-complement complex in which the antibody is rabbit anti-BSA IgG $\mathrm{F}\left(\mathbf{a b}^{\prime}\right) 2$ fraction; $\mathrm{AgAbC}$, antigen-antibody-complement complex; FITC, fluorescein isothiocyanate; SRBC, sheep erythrocyte; IgMEAC, SRBC sensitized with IgM antibody and complement.
\end{abstract}


by either indirect immunofluorescence (Theofilopoulos, 1974b) or by radiolabeling (Eden, 1973). Complement receptor cells can also be identified by incubation with complexes of heat aggregated IgG and complement (Dukor, 1973). These studies have employed whole IgG molecules to fix complement (Dukor, 1973; Eden, 1973; Theofilopoulos, 1974b). The presence of whole IgG may permit binding to both $\mathrm{Fc}$ and $\mathrm{C} 3$ receptors. Radiolabeled or fluorescein conjugated fluid-phase complement components will also detect complement receptors (Theofilopoulos, 1974a).

This paper reports the use of soluble immune complexes for the specific detection of complement receptor lymphocytes. Human complement was fixed to preformed immune complexes containing IgG $\mathrm{F}\left(\mathrm{ab}^{\prime}\right) 2$. The binding of these complexes to complement receptors was detected by immunofluorescence.

\section{MATERIALS AND METHODS}

\section{Sera}

The intact IgG fraction of rabbit anti-BSA, the $\operatorname{IgG} F\left(a b^{\prime}\right) 2$ fraction of rabbit anti-BSA, unlabeled and fluorescein isothiocyanate (FITC)-conjugated BSA (twice crystallized), and the IgG fraction of rabbit anti-sheep erythrocyte serum were obtained from Cappel Laboratories (Cochranville, PA); the IgM fraction of rabbit anti-sheep erythrocyte serum was obtained from Cordis (Miami, FL); and rabbit anti-sheep ery throcyte serum (hemolysin) was purchased from BBL, division Becton-Dickinson (Cockeysville, MD). Goat anti-human C3 conjugated with FITC was purchased from Hyland (Costa Mesa, CA) and rabbit anti-human $\mathrm{C} 4$ conjugated with FITC from Behring Diagnostics (Somerville, NJ). The specificities of these anti-human C3 and $\mathrm{C} 4$ sera were established by immunoelectrophoresis against human serum and by immunodiffusion against the appropriate antigen.

\section{Complement}

Normal human serum (NHS) and mouse (AKR) serum were used for complement. Complement was inactivated by heating $\left(56^{\circ} \mathrm{C}, 30 \mathrm{~min}\right)$.

\section{Molecular complexes}

Immune complexes of BSA-anti-BSA $(\mathrm{AgAb})$ were prepared by the method of Reid (1971). The equivalence point was determined by mixing, in equal volumes, doubling dilutions of either rabbit anti-BSA IgG (16.4 $\mathrm{mg} / \mathrm{ml})$ or rabbit anti-BSA $\operatorname{IgG} \mathrm{F}\left(\mathrm{ab}^{\prime}\right) 2(9.6 \mathrm{mg} / \mathrm{ml})$ in Veronal buffered saline (VBS), $\mathrm{pH} 7.5$ with BSA $(130 \mu \mathrm{g}$ per $\mathrm{ml})$; the mixtures were incubated at $37^{\circ} \mathrm{C} 1 \mathrm{~h}$ and then $4^{\circ} \mathrm{C}$ for $18 \mathrm{~h}$. At equivalence the antibody concentration was $2.4 \mathrm{mg} / \mathrm{ml}$ for IgG $\mathrm{F}\left(\mathrm{ab}^{\prime}\right) 2$ and $4.1 \mathrm{mg} / \mathrm{ml}$ for IgG. For labeling experiments, 4 -fold antibody excess was used in order to avoid precipitation of the AgAb complexes. NHS (1:2 in VBS) was added to an 
equal volume of AgAb complex, and incubated for $60 \mathrm{~min}$ at $37^{\circ} \mathrm{C}$, thus forming $\mathrm{BSA}$-anti-BSA-C (AgAbC).

Aggregated human IgG (AggIgG) was prepared by incubation at $63^{\circ} \mathrm{C}$ for $20 \mathrm{~min}$ and centrifugation at $1000 \mathrm{~g}$ for $30 \mathrm{~min}$ at $4^{\circ} \mathrm{C}$ prior to use.

\section{Estimation of complement fixation}

$0.5 \mathrm{ml}$ of NHS was added to $0.375 \mathrm{ml}$ of preformed immune complexes, and incubated at $37^{\circ} \mathrm{C}$ for $1 \mathrm{~h}$. The tubes were then centrifuged at $5000 \mathrm{~g}$ for $30 \mathrm{~min}$ at $4^{\circ} \mathrm{C}$. The number of residual $\mathrm{CH} 50$ units in the supernatants was determined by the method of Kabat and Mayer (1961), and compared with NHS incubated without immune complexes.

\section{Cells}

Human peripheral blood mononuclear cells were separated from venous blood on a Ficoll-Hypaque gradient as previously described (Deegan, 1976). Sheep red blood cells (SRBC) in Alsever's solution were purchased from BBL (Cockeysville, MD).

\section{Immunofluorescence}

One hundred $\mu \mathrm{l}$ of fluorescein-conjugated complexes $\left(480 \mu \mathrm{g}\right.$ of $\mathrm{F}\left(\mathrm{ab}^{\prime}\right) 2$ complex or $820 \mu \mathrm{g}$ of IgG complex) were added to $100 \mu \mathrm{l}$ of mononuclear cells $\left(2 \times 10^{5}\right.$ cells $)$ and incubated for $30 \mathrm{~min}$ at room temperature. The cells were washed in cold VBS and centrifuged at $200 \mathrm{~g}$. The cells were examined with a Leitz Ortholux II microscope equipped with epifluorescence (selective FITC excitation) and phase illumination. A minimum of 200 cells was counted and the percentage of positive cells with membrane fluorescence was determined. Blocking studies were carried out by preincubating the cells with an equal volume of AggIgG $(1 \mathrm{mg} / \mathrm{ml})$ for $30 \mathrm{~min}$ at room temperature, washing three times in cold VBS and incubating with AgAbC as above.

The presence of cell-bound human C3 or C4 on mononuclear cells was determined. The cells were incubated with AgAbC containing unlabeled $\mathrm{BSA}$, washed 3 times, and incubated for $30 \mathrm{~min}$ at room temperature with $100 \mu$ l of either FITC conjugated anti-human C3, or anti-human C4. The cells were washed and examined for membrane fluorescence.

\section{Rosette assay}

Sheep RBC (SRBC) sensitized with rabbit anti-SRBC (IgM fraction) and mouse complement (IgMEAC-Mo) were prepared as previously described (Deegan, 1976). NHS $(1: 100)$ was used to prepare IgMEAC-Hu. Equal volumes of IgMEAC $\left(10^{8}\right.$ cells $\left./ \mathrm{ml}\right)$ and mononuclear cells $\left(2 \times 10^{5}\right.$ cells $)$ were incubated at $37^{\circ} \mathrm{C}$ for $30 \mathrm{~min}$. After gentle resuspension, 200 cells were counted. Those cells binding 3 or more reagent red cells were recorded as positive. As a control, complement was omitted from the sensitization procedure and the reagent cells (IgMEA) were incubated with mononuclear cells as above. Binding of IgMEA to mononuclear cells was never observed. 
Conditions which might have permitted $\mathrm{T}$ cell (E) rosette formation (i.e., centrifugation and cold incubation) were avoided.

Blocking of rosette formation by $B S A-F\left(a b^{\prime}\right) 2-C$

The concentration of immune complexes required to prevent subsequent rosette (IgMEAC) formation on a standard concentration of mononuclear cells was determined. Fifty $\mu$ l of mononuclear cells $\left(10^{5}\right.$ cells $)$ were added to doubling dilutions of $375 \mu \mathrm{l}$ of the BSA-F(ab')2-C complexes and incubated for $30 \mathrm{~min}$ at room temperature. Unbound immune complexes were removed by 3 washes in cold VBS. The cells were incubated with $50 \mu \mathrm{l}$ of IgMEAC $\left(10^{8}\right.$ cells $\left./ \mathrm{ml}\right)$ for $30 \mathrm{~min}$ at $37^{\circ} \mathrm{C}$. Both IgMEAC-Mo and IgMEAC-Hu were tested.

\section{RESULTS}

\section{Complement fixation}

Experiments were carried out to confirm the ability of rabbit IgG F(ab')2 to fix human complement. The normal human serum used in these assays contained $128 \mathrm{CH} 50$ units per $\mathrm{ml}$. Following incubation with preformed BSA-F $\left(a b^{\prime}\right) 2$ complexes the serum contained 64 CH50 units per ml, indicating $50 \%$ of the hemolytic complement had been fixed by the preformed immune complexes.

\section{Blocking of complement receptors by $B S A-F\left(a b^{\prime}\right) 2-C$}

AgAbC (BSA-F $\left.\left(\mathrm{ab}^{\prime}\right) 2-\mathrm{C}\right)$ inhibited rosette formation at dilutions less than 1: 32 (>60 $\mu \mathrm{g}$ complex added) (fig. 1). This inhibitory activity declined precipitously at $1: 32$, and was not detected at lower concentrations of $\mathrm{AgAbC}$. The concentration of $\mathrm{AgAbC}$ used in subsequent experiments was $480 \mu \mathrm{g} / 2 \times 10^{5}$ cells which was well within the range of maximum blocking of complement receptor sites (fig. 1).

\section{Binding of BSA-F(ab')2-C to complement receptors}

The identification of complement receptor cells with fluoresceinated $\mathrm{AgAbC}$ is demonstrated in fig. 2. This method is compared with the IgMEAC-Mo rosette assay using peripheral blood mononuclear cells from a number of normal volunteers (fig. 3). The straight line was determined by linear regression analysis using the least-squares method and has a slope of 1.168 and $y$-intercept of -0.089 . Although the two methods demonstrated a relatively good correlation $(r 0.78)$, it was noted that the percent binding with the fluorescence method was generally higher than the corresponding rosette assay. A paired $t$-test indicated a statistically significant difference $(P<0.001)$ between the two techniques. 


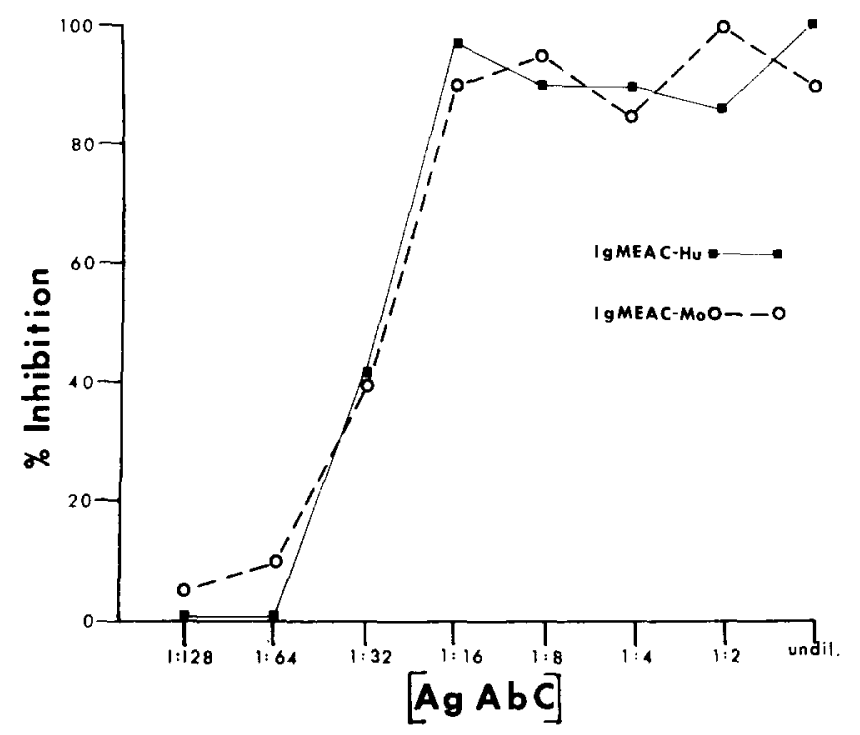

Fig. 1. Inhibition of IgMEAC rosettes by BSA-F(ab')2-C (AgAbC). Each point represents the mean of duplicates, and all are from the same donor. Control values were $12 \%$ for IgMEAC-Mo and $15 \%$ for IgMEAC-Hu. Undiluted AgAbC contained $1.80 \mathrm{mg}$ of complex in $375 \mu \mathrm{l}$.

Specificity of BSA-F(ab')2-C for complement receptors

Studies were undertaken to demonstrate that binding observed with BSA-F $\left(\mathrm{ab}^{\prime}\right) 2-\mathrm{C}$ was specific for complement receptors and not due to $\mathrm{Fc}$ receptor activity. The binding of $\mathrm{BSA}-\mathrm{F}\left(\mathrm{ab}^{\prime}\right) 2-\mathrm{C}$ was compared with com-

TABLE 1

Specificity of immune complex detection of complement receptors *.

\begin{tabular}{llc}
\hline 1st Incubation & 2nd Incubation & \% Positive \\
\hline AgAbc (intact IgG) & None & 20.0 \\
AgAbC (F(ab')2) & None & 17.5 \\
AggIgG & AgAbC (Intact IgG) & 15.0 \\
AggIgG & AgAbC (F $\left.\left(\mathrm{ab}^{\prime}\right) 2\right)$ & 17.0 \\
AgAbC (intact IgG) & Anti-C3-FITC & 20.0 \\
AgAbC (intact IgG) & Anti-C4-FITC & 9.5 \\
AgAbC $\left(\mathrm{F}\left(\mathrm{ab}^{\prime}\right) 2\right)$ & Anti-C3-FITC & 13.5 \\
AgAbC $\left(\mathrm{F}\left(\mathrm{ab}^{\prime}\right) 2\right)$ & Anti-C4-FITC & 0 \\
\hline
\end{tabular}

* First incubations were performed at room temperature for $30 \mathrm{~min}$. The cells were subsequently washed three times in cold VBS, incubated with the second set of reagents, washed and examined for fluorescence. 


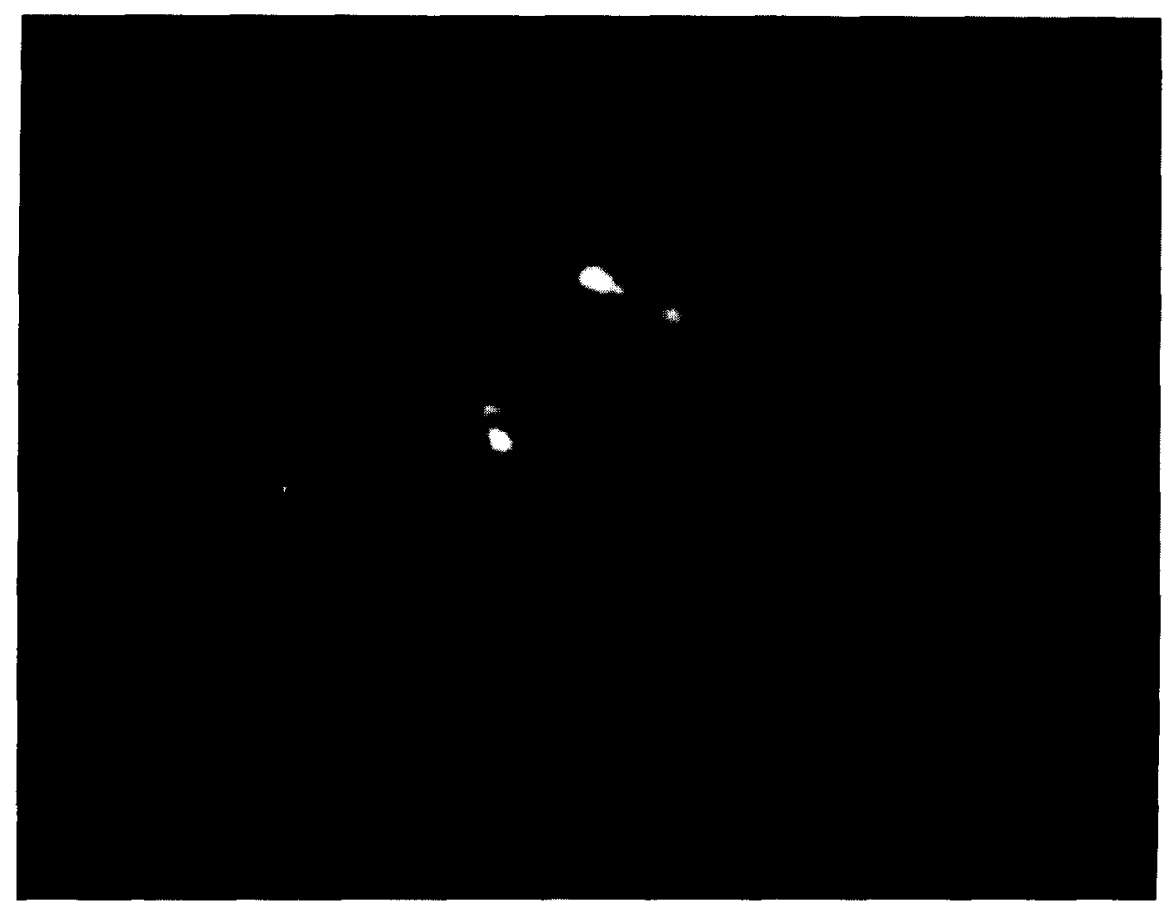

Fig. 2. Fluorescence of BSA-F(ab')2-C (AgAbC) which is bound to a human peripheral blood lymphocyte. Punctate fluorescent complexes are present at the cell membrane. Ultraviolet illumination, $\times 540$.

plexes prepared with intact IgG. AgAbC containing intact IgG showed slightly higher binding than did BSA-F $\left(a^{\prime}\right) 2-C$ (table 1). However, one-fourth of the binding seen with intact IgG could be inhibited by prior incubation of the cells with AggIgG for $30 \mathrm{~min}$ at room temperature (20\% vs 15\%). BSA$\mathrm{F}$ (ab')2-C binding was not inhibited by AggIgG (table 1). If complement was not added to the complexes, or if heated complement was substituted for fresh serum, only $1 \%$ binding occurred.

\section{Pathway of complement activation}

Since $\mathrm{C} 4$ does not participate in the alternate pathway, whereas both $\mathrm{C} 3$ and $\mathrm{C} 4$ are activated in the classic pathway, these two pathways can be distinguished by the presence of C4 (Osler, 1976). Using immunofluorescence, $\mathrm{C} 3$, but not $\mathrm{C4}$, was detected on the surface of cells preincubated with BSA-F $\left(a b^{\prime}\right) 2-C$ (table 1). Both $\mathrm{C} 3$ and $\mathrm{C} 4$ were present on those cells preincubated with $\mathrm{AgAbC}$ prepared with intact IgG. The percentage of cells binding complexes was comparable with anti-C3 and fluoresceinated AgAbC (table 1). 


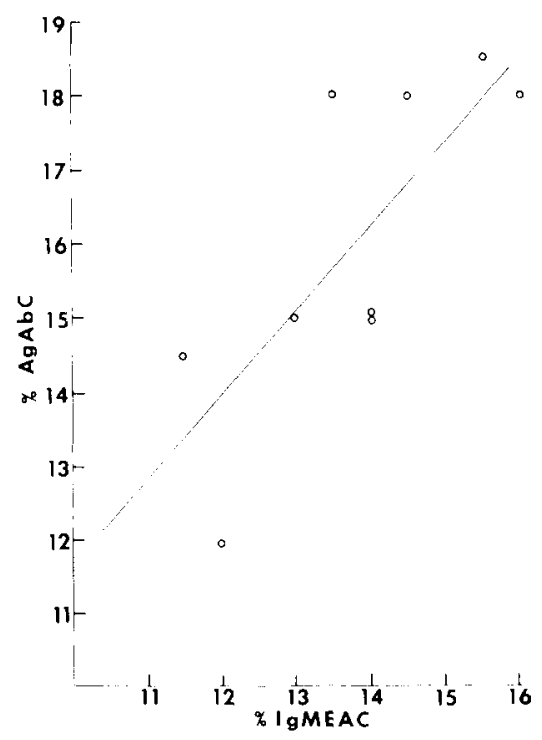

Fig. 3. Comparison of fluorescent BSA-F $\left(a b^{\prime}\right) 2-C$ ( $\left.A g A b C\right)$ and rosette (IgMEAC) assays on normal peripheral blood lymphocytes. The percentage of cells binding either AgAbC or IgMEAC from normal donors is indicated by the circles. Each point represents the mean of duplicates. The straight line was determined by the least-squares method for linear regression; slope $=1.168, y$-intercept $=-0.089$, and $r=0.78$. Mean \pm 1 S.D. for $\operatorname{IgMEAC}=13.78 \pm 1.40$ and for $\mathrm{AgAbC}=16.0 \pm 2.09, P<0.001$

\section{DISCUSSION}

We have described an immunofluorescent technique for the specific identification of complement receptors on human peripheral blood mononuclear cells. Although this method correlates well with the IgMEAC rosette assay ( $r$ 0.78) the percentage of cells binding $\mathrm{BSA}-\mathrm{F}\left(\mathrm{ab}^{\prime}\right) 2-\mathrm{C}$ is significantly higher than the percentage binding IgMEAC $(P<0.001)$. This difference is not due to Fc receptor binding of $\mathrm{BSA}-\mathrm{F}\left(\mathrm{ab}^{\prime}\right) 2-\mathrm{C}$, since binding was not reduced by preincubation of the cells with AggIgG, which blocks Fc receptor sites. The increased number of positive cells observed with BSA-F $\left(a b^{\prime}\right) 2-C$ indicates this technique is more sensitive than the rosette assay. The smaller size of the complexes in the fluorescence method may account for the increased sensitivity. Soluble reagents have been observed to be more sensitive than particulate complexes (rosettes) in the detection of complement receptors on certain lymphoblastoid cell lines (Theofilopoulos, 1974b).

Rabbit IgG $F\left(a b^{\prime}\right) 2$ has been previously shown to fix guinea pig complement via the alternate pathway (Reid, 1971). In the present study C3 but nol $\mathrm{C} 4$ was present in the cell bound complexes, suggesting that rabbit IgG $\mathrm{F}\left(\mathrm{ab} \mathrm{b}^{\prime}\right) 2$ fixes human complement by the alternate pathway.

Previously, complement receptors have been detected by soluble immune 
complexes prepared with whole, intact IgG (Dukor, 1973; Eden, 1973; Theofilopoulos, 1974b). Although complement receptors are identified by these methods, there appears to be some binding to Fc receptors by IgG, since the binding can be partially inhibited by AggIgG (fig. 4). Conversely, AggIgG does not affect the binding of $\mathrm{BSA}-\mathrm{F}\left(\mathrm{ab}^{\prime}\right) 2-\mathrm{C}$. In addition, only negligible binding of BSA-F $\left(a b^{\prime}\right) 2$ occurred when complement was either deleted or heat inactivated, indicating that activated complement is required for binding to lymphocytes (fig. 5). This requirement for complement demonstrates: (1) that binding is specific for complement receptors and (2) attachment to mononuclear cells is not mediated by rabbit anti-human antibodies which might be present in the anti-serum. At high concentrations the soluble BSA$\mathrm{F}\left(\mathrm{ab}^{\prime}\right) 2-\mathrm{C}$ complexes were able to inhibit subsequent binding of IgMEAC to mononuclear cells, suggesting that both the soluble complexes and IgMEAC bind to the same receptor. Results from these studies indicate that the use of immune complexes containing $F\left(a b^{\prime}\right) 2$ appears to be a sensitive and specific method for the detection of complement receptors on peripheral blood mononuclear cells.

\section{ACKNOWLEDGEMENTS}

This work was supported by grants from the National Institute of General Medical Sciences (NIH-GM-15419-10) and the University of Michigan Cancer Research Institute.

\section{REFERENCES}

Bianco, D., R. Patrick and V. Nussenzweig, 1970, J. Exp. Med. 132, 702.

Deegan, M.J., J. Cossman, B.T. Chosney and B. Schnitzer, 1976, Cancer 38, 1952.

Dukor, P., E.R. Suter, F.M. Deitrich and P. Probst, 1973, in: Microenvironmental Aspects of Immunity, eds. B.D. Jankovic and K. Isakovic (Plenum Press, New York) p. 209.

Eden, A., C. Bianco and V. Nussenzweig, 1973, Cell. Immunol. 7, 459.

Gelfand, M.C., M.M. Frank and I. Green, 1975, J. Exp. Med. 142, 1029.

Gelfand, J.A., A.S. Fauci, I. Green and M.M. Frank, 1976, J. Immunol. 116, 595.

Gupta, S., G.D. Ross, R.A. Good and F.P. Siegal, 1976, Blood, 48, 755.

Henson, P.M., 1969, Immunology 16, 107. •

Kabat, E.A. and M.M. Mayer, 1961, Experimental Immunochemistry (Charles C. Thomas, Springfield, IL).

Lay, W.H. and V. Nussenzweig, 1968, J. Exp. Med. 128, 991.

Osler, A.G., 1976, Complement: Mechanisms and Functions. Foundation of Immunology Series (Prentice Hall, Englewood Cliffs, NJ).

Reid, K.B.M., 1971, Immu nology 20, 649.

Shevach, E.M., E.S. Jaffe and I. Green, 1973, Transplant. Rev. 16, 3.

Theofilopoulos, A.N., V.A. Bokisch and F.J. Dixon, 1974a, J. Exp. Med. 139, 696.

Theofilopoulos, A.N., F.J. Dixon and V.A. Bokisch, 1974b, J. Exp. Med. 149, 877. 